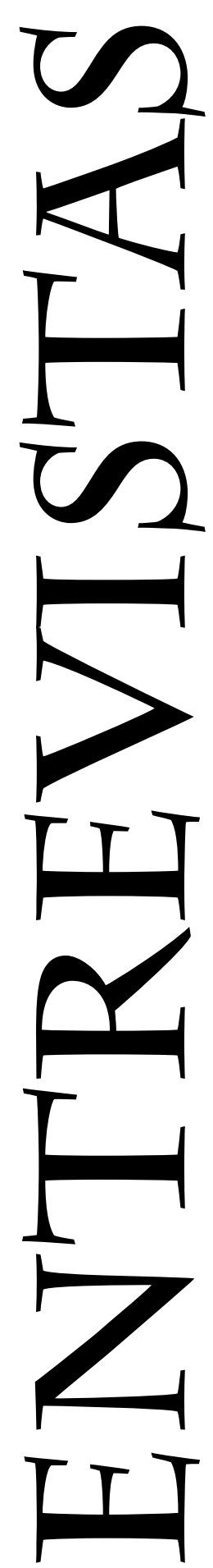




\title{
Ecos Armoriais: entrevista com Clóvis Pereira
}

\author{
Marília Paula dos Santos \\ Universidade Federal de Pernambuco | Orcid: 0000-0003-0043-0863
}

\begin{abstract}
Resumo: Clóvis Pereira é um compositor brasileiro de música para concerto. Destaca-se por enfatizar em suas composiçôes características que estão presentes nas culturas populares da região Nordeste do Brasil. Esse olhar voltado para sua própria cultura está relacionado com a vida do próprio compositor e com as aulas que ele teve, nos anos cinquenta do século XX, com o compositor César Guerra-Peixe. No final dos anos sessenta Clóvis Pereira foi convidado pelo escritor Ariano Suassuna para fazer parte de um grupo que estava buscando criar uma arte "erudita" autenticamente brasileira. Junto com Jarbas Maciel e Cussy de Almeida, Clóvis Pereira foi um dos artistas responsáveis por criar o que ficou conhecido como música armorial, que foi lançada oficialmente em 18 de outubro de 1970, com a Orquestra Armorial. Dos três primeiros músicos “armoriais” apenas Clóvis Pereira permanece vivo. Em 2017 Marília Santos o entrevistou para uma pesquisa sobre as influências armoriais na música atual do estado de Pernambuco. Nesse texto apresentamos os principais trechos dessa entrevista.
\end{abstract}

Palavras-chave: Clóvis Pereira; Música Armorial; Musicologia.

\section{Armorials Echoes: interview with Clóvis Pereira}

\begin{abstract}
Clóvis Pereira is a Brazilian concert music composer. He stands out for emphasizing in his compositions characteristics that are present in the popular cultures of the Northeast region of Brazil. This interest in his own culture is related to the life of the composer and to the classes he took, in the fifties of the 20th century, with the composer César Guerra-Peixe. In the late sixties, Clóvis Pereira was invited by the writer Ariano Suassuna to be part of a group that wanted to create an "classic" authentically Brazilian art. Together with Jarbas Maciel and Cussy de Almeida, Clóvis Pereira was one of the artists responsible for creating what became known as armorial music, which was officially launched on October 18, 1970, with the Orquestra Armorial. Of the first three "armorial" musicians only Clóvis Pereira is alive. In 2017 Marília Santos interviewed him for a research on armorial influences in the current music of the state of Pernambuco. In this text we present the main excerpts of this interview.
\end{abstract}

Keywords: Clóvis Pereira; Armorial Music; Musicology.

\section{Ecos Armoriales: entrevista con Clóvis Pereira}

Resumen: Clóvis Pereira es un compositor brasileño de música de concierto. Se destaca por enfatizar en sus composiciones características que están presentes en las culturas populares de la región Nordeste de Brasil. Esta mirada dirigida a su propia cultura se relaciona con la propia vida del compositor y con las clases que tomó, en los años cincuenta del siglo XX, con el compositor César Guerra-Peixe. A finales de los sesenta, Clóvis Pereira fue invitado por el escritor Ariano Suassuna a formar parte de un grupo que buscaba crear un arte "alto" auténticamente brasileño. Junto a Jarbas Maciel y Cussy de Almeida, Clóvis Pereira fue uno de los artistas encargados de crear lo que se conoció como música armourial, que se estrenó oficialmente el 18 de octubre de 1970, con la Orquestra Armourial. De los tres primeros músicos "armónicos", sólo queda con vida Clóvis Pereira. En 2017, Marília Santos lo entrevistó para una investigación sobre las influencias de las armaduras en la música actual del estado de Pernambuco. En este texto presentamos los principales extractos de esta entrevista.

Palabras Clave: Clovis Pereira; Música Armorial; Musicología. 


\section{Tntroduçáo}

Clóvis Pereira dos Santos é uma compositor brasileiro de música para concerto. Ele nasceu na cidade de Caruaru, agreste do estado de Pernambuco, em 14 de maio de 1932. Filho de músico - o clarinetista Luiz Gonzaga Pereira dos Santos - não foi difícil para o compositor desenvolver suas habilidades musicais, que não se limitam somente aos processos criativos. Ele destaca-se por enfatizar em suas composições características que estáo presentes nas culturas populares da região Nordeste do Brasil, com ênfase para o interior, onde viveu sua infância e grande parte da sua adolescência. Esse olhar nas suas composiçôes, voltado para a própria cultura, está relacionado com a sua vida e também com a influência do compositor fluminense César Guerra-Peixe (1914-1993), com quem Clóvis Pereira teve aulas, durante os anos cinquenta, ao lado de outros três grandes compositores da música brasileira: Lourenço da Fonseca Barbosa, o Capiba (1904-1997), Severino Dias de Oliveira, o Sivuca (1930-2006) e Jarbas Maciel (1932 ou 1933²-2019).

No final dos anos sessenta Clóvis Pereira foi convidado pelo escritor Ariano Suassuna (1927-2014) para fazer parte de um grupo que estava buscando criar uma arte erudita ${ }^{2}$ autenticamente brasileira. Junto com Jarbas Maciel e Cussy de Almeida (1936-2010), Clóvis Pereira foi um dos artistas responsáveis por criar o que ficou conhecido como música armorial. A música armorial foi lançada oficialmente no dia 18 de outubro de 1970, junto com a inauguração do Movimento Armorial, na igreja de São Pedro dos Clérigos, em Recife, capital do estado de Pernambuco (Moraes, 2000³; Nóbrega, 2000 $2007^{5}$; Pereira, 20176; Santos, $\left.2017^{7}, 2019^{8}, 2020^{9}\right)$.

$\mathrm{O}$ armorial foi um movimento que buscou criar uma arte brasileira, tendo como base para sua criação as culturas populares do interior da região Nordeste do Brasil. Ariano Suassuna reuniu um grupo de artistas, nas diversas áreas, para criar a arte nacional que desejava. Ele, junto com o Movimento Armorial, acreditava que a verdadeira e mais "pura" 1 Náo conseguimos descobrir ao certo qual o ano em que Jarbas Maciel nasceu. Porém sabemos que o mesmo faleceu aos 86 anos em 2019.

2 Não gostamos do nome "erudito/a", pois, mesmo que de forma indireta, dá a entender que não há erudição nas coisas que não são categorizadas como eruditas, sobretudo as populares. Entretanto, "erudito" e "popular" são palavras que estão bastante presentes no discurso armorial. Desta forma, não há como falar em armorial sem apresentar esses termos.

3 MORAES, Maria Thereza Didier. Emblemas da Sagração Armorial: Ariano Suassuna e o Movimento Armorial 1970/76. Recife: Editora Universitária da UFPE, 2000.

4 NÓBREGA, Ariana Perazzo da. A música no Movimento Armorial. Dissertação (Mestrado em Música). Universidade Federal do Rio de Janeiro, Rio de Janeiro, 2000.

5 NÓBREGA, Ariana Perazzo da. A música no Movimento Armorial. In Anais da Anppom. 2007, p. 1-13. Disponível em $<$ https://hugoribeiro.com.br/biblioteca-digital/Nobrega-musica movimento armorial.pdf.>. Acesso em 01 ago. 2020.

6 PEREIRA, Clóvis. Entrevista de Marília Santos. Áudio. Recife. Em 13 mar. 2017.

7 SANTOS, Marília P. Ecos Armoriais: influências e repercussão da Música Armorial em Pernambuco. Dissertação (Mestrado em Música). Universidade Federal da Paraíba, Joáo Pessoa, 2017.

8 SANTOS, Marília P. Ecos Armoriais: influência e repercussão da Música Armorial em Pernambuco. Música Popular em Revista, v. 2, ano 6, jul.-dez. 2019, p. 29-54.

9 SANTOS, Marília P. Música armorial: revisáo bibliográfica. Revista Música, v. 20, n. 2, dez. 2020, p. 63-98. 
brasilidade estava no interior do Nordeste, por conta do atraso econômico que esses lugares sofriam. Logo, eles náo eram, segundo Suassuna, influenciados pelo cosmopolitismo e pela "modernidade". As mudanças que aconteciam às culturas desses locais mantinham, para o escritor, uma particularidade própria que não as descaracterizava (Moraes, 2000; Santos, 2017, 2019, 2020; Suassuna, $1974^{10}$ ).

Das artes, a música foi uma das que mais se destacou. Após mais de 51 anos desde o lançamento do Movimento Armorial, ainda é possível encontrar, não somente no estado de Pernambuco e na regiáo Nordeste, pessoas compondo e performatizando músicas com atributos que podem ser apontados como armoriais (Santos, 2017, 2019). Em 2017 eu entrevistei Clóvis Pereira, para entender o que foram a música e o Movimento Armorial, como os primeiros músicos se conheceram e como Ariano Suassuna chegou até eles. Para então, junto com outras entrevistas e estudos, apontar as influências e repercussão do armorial, os ecos armoriais, na música atual de Pernambuco, numa pesquisa financiada pela Coordenaçáo de Aperfeiçoamento de Pessoal de Nível Superior (CAPES), e orientada pelo etnomusicólogo e professor Dr. Carlos Sandroni, no Programa de Pós-graduação em Música da Universidade Federal da Paraíba.

Dos três primeiros músicos "armoriais" apenas Clóvis Pereira permanece vivo. Entendendo a importância de Clóvis Pereira para a música brasileira e sua contribuição para a música armorial, decidimos publicar as principais partes da entrevista que realizamos com ele, para que esse relato táo importante fique registrado e que outros/as/es pesquisares/as possam utilizá-lo em suas investigaçóes.

\section{Clóvis Pereira: entrevista de Marília Santos}

A entrevista a seguir foi realizada no dia 13 de março de 2017, na casa do Clóvis Pereira, no bairro de Boa Viagem, em Recife, onde ele mora atualmente. Foi gravada em áudio e feita para a pesquisa sobre os ecos armoriais na música. Ao realizá-la, Clóvis Pereira permitiu que eu a utilizasse para a pesquisa e, consequentemente, para publicaçáo. Por conta da qualidade náo muito boa do aparelho que utilizei para gravar a entrevista, há alguns pequenos trechos, algumas palavras, que ficaram inaudíveis. Porém, isto não atrapalha na compreensão geral do que foi relatado pelo Clóvis Pereira e, táo pouco, diminui a importância desse conteúdo.

Marília Santos: Primeiro eu gostaria de lhe agradecer, muito, por me conceder essa entrevista, pois para mim isso é muito importante, tanto pela pesquisa em si, porque eu estou tratando do armorial, e o senhor fez parte direta do Movimento Armorial, e por isso é extremamente importante ouvir sua fala, mas também de uma forma pessoal, porque não é todo mundo que tem a oportunidade de conversar com Clóvis Pereira.

Clóvis Pereira: Eu agradeço também a sua atenção e o seu interesse. Esse Movimento Armorial quando começou não tinha nome. Ariano há tempos, há anos atrás, antes dos anos setenta, num livro chamado $\dot{E}$ de Tororó, que foi editado no Recife, ele mostrava interesse de desenvolver uma arte brasileira. Ele era poeta, escrevia seus 
versos, peças de teatro. Aí um dia ele resolveu que a música também tinha, deveria ter esse traço de brasilidade, de nordestinidade, principalmente. E como ele era um homem que também foi criado no interior, ele admirava a música dos cantadores de viola, a música dos aboiadores. E ele conheceu um aluno na Universidade [Federal de Pernambuco], aluno dele, que era músico. Fizeram amizade. E esse rapaz se chamava, esse músico se chamava, se chama, porque ele ainda é vivo, Jarbas Maciel. Então ele convidou Jarbas para fazer umas pesquisas musicais e desenvolver essas pesquisas, com a finalidade de apresentá-las. Não da maneira que elas foram ouvidas, mas com um certo desenvolvimento, técnico, tonal, rítmico, que guardassem as impressóes do que elas realmente seriam, eram, do que elas apresentavam ser, mas que elas fossem transformadas numa espécie de música que não teriam que ser popularizadas, entendes? Então ele queria fazer uma espécie de música para ouvir, música de câmara, música que pudesse ensejar composição de um concerto, de uma sonata. E o Jarbas disse: "Bom, aqui eu não posso fazer esse trabalho só. Mas existem duas pessoas..." que ele conhecia, e indicou [para Ariano Suassuna]. Uma delas foi o professor Cussy de Almeida, que tocava muito bem o violino, formado na Europa, mas que também era nordestino, natural do Rio Grande do Norte. E disse: "Tem Clóvis Pereira, que estudou junto comigo, com Guerra-Peixe, nos anos cinquenta." Isso era início dos anos setenta. E nós fizemos uma reunião. Eu, Cussy, Jarbas e Ariano. Fizemos uma reunião e traçamos... Ariano traçou a diretrizes. E nós concordamos. Porque, como nós [Clóvis Pereira e Jarbas Maciel] havíamos estudado com Guerra-Peixe... Guerra -Peixe tinha deixado o Rio de Janeiro para vir morar em Pernambuco, porque ficou encantado com o folclore. Ele veio para estudar o frevo, o caboclinho, o maracatu. Eu acho que essas foram as grandes fontes de Guerra-Peixe. Cantiga de cego... tudo que era nordestino. E ele tem várias obras, não com o sentido armorial, mas com o sentido nordestino.

Marília Santos: Então Guerra-Peixe não é armorial?

Clóvis Pereira: Não.

Marília Santos: Ele [Guerra-Peixe] tem música nordestina. Sim?

Clóvis Pereira: Nordestinas. Ele compôs umas duas peças por encomenda de Ariano. Como ele tinha também esse sentido nordestino, ele se enquadrou. A gente não pode dizer que ele participou do Movimento [Armorial], mas ele foi convidado, depois do movimento, para escrever algumas peças [parte meio inaudível] [como meio] de dinamizar o que ele tinha. Ele era vivo e escrevia várias obras do Brasil, por ser de circunstâncias brasileiras, de Mário de Andrade. E essa coisa de brasilidade, ele tinha também a esperança de criar uma noção de música brasileira. De fato, ele estudou o folclore daqui, estudou o folclore, depois, de São Paulo, e escreveu várias peças. [Agora Clóvis Pereira volta a falar das reunióes para o Movimento Armorial]. Quando nós começamos as reunióes, Ariano trazia os cantadores do interior. Trazia um rabequeiro, às vezes outro rabequeiro, um tocador de viola. E a gente ia ouvindo essa coisa bem natural. E a gente ia anotando e gravando e fazendo as pesquisas. Depois de uns oito a dez meses, Ariano pretendeu fazer uma audição. Essa audição reuniu dois tocadores de pife, pifes. O nome é pífanos, mas eles chamam é pifes. $\mathrm{E}$ nós escrevemos peças, três ou quatro peças, eu, Jarbas e Cussy escrevemos de umas 
quatro a cinco peças. Pecinhas curtas, de três, quatro minutos, para mostrar o que seria essa nova música de câmara. Duas flautas... Aí nós contratamos [inaudível]. Ariano contratou, convidou. Um violão, para manter a característica da viola sertaneja, essa coisa toda. Um violino, para mostrar a rabeca. O modo de tocar dos rabequeiros. $\mathrm{E}$ uma viola. Viola de orquestra, viola de arco, para fazer uma espécie de contracanto, uma espécie de um diálogo, que não chegaria a ser um desafio. A intenção também não era essa. Mas era de fazer um contraponto entre os dois instrumentos [acreditamos que ele está falando do violino e da viola de arco]. Uma base harmônica na viola... no violáo, sem descaracterizar o encadeamento dos acordes. Nós eliminávamos os acordes que tivessem certas dissonâncias. Os acordes que caracterizam a música europeia. [...]. Usávamos uns acordes simples. E combinados entre si, os acordes teriam que refletir a maneira de colocar os acordes que o povo colocava.

Marília Santos: E esses acordes que o senhor fala que remetem à música da Europa, quais seriam eles?

Clóvis Pereira: Ah, seria o acorde de tônica. A dominante não teria função de dominante. Ela era substituída por um outro acorde. Poderia ser até um acorde da subdominante. Mas que devido às posiçóes dos instrumentos, eles repetiam a posição do instrumento e botavam um acorde que não tinha sentido europeu. Entendes? Então nós chegamos até a fazer um trabalho... Eu não tenho mais esse trabalho, meu Deus, eu não sei por que. Quando eu fui fazer o mestrado em Boston, eu elaborei essa teoria, mandei para a CAPES, que havia me dado a bolsa para estudar lá [inaudível]. [Aqui ele explica que depois de realizar esse trabalho, para o mestrado, ele perdeu o material e não conseguiu mais encontrá-lo. Também explica que já se passaram mais de vinte anos desde que ele fez esse mestrado. Na época os trabalhos não eram digitalizados. Ele fez em uma máquina de datilografar, de escrever, como ele contou. Enfatiza que o trabalho dele falava de como harmonizar uma música armorial. Agora ele continua falando sobre a melodia armorial]. Porque a melodia armorial a gente já fazia, baseando-se nas nossas escalas modais. Muito antes de a gente fazer esse trabalho, parece que Zé Siqueira ${ }^{11}$ já falava num sistema que ele denominou Trimoldal Brasileiro. A gente usava harmonias e reminiscências melódicas que ficaram aqui no interior devido aos povos que nos colonizaram. Povo que veio da Europa... veio da Espanha e veio do sul de Portugal, uma coisa assim. Ariano explicava isso a gente. E nós tínhamos uma noção. Mas não havíamos pesquisado. Então a gente ficou usando a escala maior, com a sétima abaixada.

Marília Santos: Qualquer escala maior? Ou tinha alguma específica?

Clóvis Pereira: Eram as mais simples, né? Era a escala de Ré maior, escala de Lá maior. Todas com a sétima abaixada e/ou a quarta aumentada. Por exemplo, Dó, Ré, Mi, Fá\# (sustenido), Sol, Lá. Não tinha o Si natural, de jeito nenhum.

Marília Santos: Para não fazer a sensível, né?

Clóvis Pereira: É. Para não fazer a sensível. E o Sib (bemol).

Marília Santos: No caso, é o que a gente chama de escala nordestina?

11 José Siqueira (1907-1985) foi um compositor brasileiro.

ICTUS Music Journal vol. 15 n.2 
Clóvis Pereira: É. De escala nordestina. Por exemplo [Ele exemplifica solfejando, cantando as notas com seus respectivos nomes]: Dó, Mi, Sol, Si, Lá, Sol, Mi, Si, Sol, Lá, Fá, $\mathrm{Mi}$, Fá, Sol. ${ }^{12} \mathrm{E}$ a sétima abaixada, com a quarta natural. E às vezes [Ele exemplifica mais uma vez solfejando]: Dó, Mi, Sol, Si, Dó, Lá, Fá, Sol, Mi, Fá, Ré, Mi, Dó, Fá, aumentada, Sol, Lá, Si, Dó, Si, Lá, Sol, Lá, Fá, Ré... Aí quando eu queria diferenciar, fazia o Fá natural. Aí entrava de novo com o acorde de Fá maior, que de qualquer maneira pertencia a Dó. E ficava fácil no instrumento para eles. Então as tonalidades mais usadas eram essas. Muito raramente aparecia a escala de Mi maior, já por causa dos sustenidos que eram muitos, né? E eles preferiam usar aquelas escalas com as quais eles estavam acostumados, com aquele som. E os cantores, os aboiadores usavam também a sétima abaixada.

Marília Santos: Se o senhor fosse definir música armorial, como o senhor definiria? O que é a música armorial?

Clóvis Pereira: A música armorial é aquela baseada nas escalas nordestinas, que tem a sétima abaixada e tem a quarta aumentada, e às vezes aparece com a terça abaixada, mas não como uma nota real. Porque a terça abaixada, dependendo do contexto melódico, ela pertence ao jazz, por exemplo [exemplifica cantarolando sem nome de notas]: [...] Aí eles usam também no jazz a sétima abaixada e usam a terça abaixada. Mas no contexto melódico que eles empregam não lembra jamais a música nordestina.

Marília Santos: E para o senhor onde é que a gente encontra essa diferença? O que é que faz uma música que usa a "mesma" escala ser tão diferente de outra?

Clóvis Pereira: A rítmica melódica e a inflexão que se dá também a essas notas. Eu diria que na música nordestina elas não insistem muito num lugar só e com aparecimento de outras notas, né? E depois com os acordes empregados. Porque quando o americano faz [exemplifica cantarolando sem nome de notas]: [...] Esse [exemplifica cantarolando sem nome de notas]: [...] é um outro acorde. Que na música nordestina seria diferente.

Marília Santos: Então, no caso, é o conjunto do todo, né?

Clóvis Pereira: É o conjunto. É a organização desses intervalos na harmonia ${ }^{13}$ melódica. Os acordes que recaem sobre essas notas estranhas, entre parênteses, porque são da escala natural, e o ritmo e, no fim de tudo, a interpretação.

Marília Santos: Para o senhor, hoje existe música armorial sendo produzida atualmente?

Clóvis Pereira: Não. Muito pouco.

Marília Santos: E esse muito pouco, onde é que a gente encontra?

Clóvis Pereira: Olhe, eu escrevo alguma coisa quando estou inspirado e tal. E deixo por

12 Como a qualidade da gravação não está boa, preferimos não transcrever os trechos em que Clóvis Pereira solfeja, para não corrermos o risco de fazermos uma transcrição errada. A transcrição aqui, e nos próximos trechos, é da fala, da língua, e não do som. Então não quer dizer que as notas são naturais. Como ele exemplifica, temos no primeiro trecho Fá sustenido e no seguinte Fá sustenido e Si bemol.

13 Essa parte do áudio ficou meio ruim. Não temos certeza se a palavra que Clóvis Pereira disse foi harmonia. 
aí. Depois vem a orquestra e toca. E depois o Rio pede, São Paulo pede. E já tem caso até da América do Norte, a Argentina pedir. Tem uma música que eu fiz com Guerra-Peixe. Aproveitei um tema de Guerra-Peixe, a pedido de Ariano. Ariano ouviu um tema de Guerra-Peixe e disse: "Olhe, você tratou mal essa música. Essa música eu queria fazer uma peça armorial para orquestra de câmara." E Guerra-Peixe lá do Rio disse: "E quem vai fazer isso?" Ele [Ariano Suassuna] disse: "É Clóvis." Ele [Guerra-Peixe] disse: "Ah, Clóvis. Pode deixar Clóvis fazer lá. Clóvis sabe fazer." E essa música hoje é tocada em todo Brasil.

Marília Santos: Mourão?

Clóvis Pereira: O Mourão. Por todas as orquestras. E eu passei um tempo para ter o reconhecimento dessa parceria. Porque Guerra-Peixe gravou esse tema cantado. E o nome que ele colocou foi "De viola e rabeca". Ele gravou com a viola, uma rabeca, uma percussáo e um cantor, com os versos, que eu não sei se ele compôs ou se adaptou de outra coisa.

Marília Santos: Onde eu encontro essa gravação? É fácil?

Clóvis Pereira: Ah, eu posso lhe dá a pista. Foi gravado em São Paulo, num LP de 10 polegadas, chamado Festa de Ritmos. Deve encontrar onde vende discos velhos. ${ }^{14}$ [Ele volta a falar da música] Porque não aconteceu. Essa música, como era cantada, não chamou muito a atenção dos chefes de orquestras. E a versão que eu fiz, ficou uma versão... que instrumento você toca?

Marília Santos: Clarinete [Não toco mais clarinete].

Clóvis Pereira: Own. Então ficou uma versão muito fácil para os violinistas tocar, porque tinha aqueles toques de rabeca, entáo ficava bonitinho. E eu desenvolvi assim: para viola, cello e violinos e contrabaixo. E botei uma percussãozinha bem leve, dispensável. Então essa orquestra daqui, do Conservatório [Pernambucano de Música], começou a ceder cópias, digamos para a Paraíba. Aí na Paraíba chegou músico de Natal, ouviu e "Ah, dá uma cópia para mim, para eu tocar." E saíram tocando, aí findou batendo no Rio de Janeiro. E do Rio de Janeiro para Sáo Paulo. E depois a OSESP, de Sáo Paulo, no tempo de John Neschling, foi há uns vinte anos atrás, aí pediu para tocar. Eu mandei, eles tocaram. E passaram a tocar nas excussóes na Europa, no Estados Unidos. E faziam um extraprograma, como um bis. Porque era uma peça pequena, de dois, três minutos. Aí o povo gostava. E os músicos gostavam de tocar. [...]. Ele às vezes botava o solo, que tinha do violino imitando a rabeca, ele colocava o chapéu de boiadeiro na cabeça do espala, o espala se levantava, fazia aquela coisa. Aí os dois músicos de percussão vinham lá de trás tocando o trecho final, vinham para frente. Aí a orquestra toda entrava. Somente cordas. E depois umas pessoas acrescentaram flautas, quer dizer, dobravam o que eu fiz.

Marília Santos: Mas a original que o senhor fez...

Clóvis Pereira: É só para cordas.

14 Nesse link, disponível no YouTube, é possível ouvir essa gravaçáo. https://www.youtube.com/watch?v=QU872e9wGzI. 
Marília Santos: É meio uma imitação da orquestra barroca?

Clóvis Pereira: Sim. A orquestra barroca. Porque nós conhecemos Ariano. Ariano primeiro não queria fazer com orquestra. Ele queria grupo pequeno. E o Cussy de Almeida era diretor do Conservatório [Pernambucano de Música]. E tinha uma orquestra, chamada Orquestra de Câmara do Conservatório Pernambucano de Música. Foi a que virou a armorial. E ele conversando com Ariano, aí fez umas apresentaçóes... Aquilo que a gente fez para um quinteto de câmara, um sexteto, aquele que estreio... Eu esqueci de dizer, estreou na casa de Francisco Brennand. ${ }^{15}$

Marília Santos: Entáo antes da estreia oficial do movimento, teve essa estreia na casa de Francisco Brennand? A estreia musical? Digamos assim.

Clóvis Pereira: Foi. A experiência. Vamos dizer que foi uma pré-estreia. Aí Ariano, que gostava muito de Brennand, por causa das pinturas... Então, assistia Brennand, a esposa, não me lembro se filho ou filha de Brennand. Mas estava presente a irmã de Ariano Suassuna, eu. Eu não tocava nada. Eu apenas ficava olhando.

Marília Santos: Porque sua parte era composição.

Clóvis Pereira: Era. Não precisava regência, porque era um grupo pequeno. E eu vou lhe dizer o nome das pessoas que trabalharam nesse concerto. $\mathrm{O}$ violonista era Henrique Annes, os flautistas eram... [Nesse momento fica um pouco difícil entender o nome do primeiro flautista. Parece que é Wallace Simóes. Clóvis explica que o filho dele, do Simóes, que na época era adolescente, tocou a segunda flauta nesse concerto. Clóvis ainda enfatiza que tanto o primeiro flautista, quanto o Henrique Annes, eram professores do Conservatório Pernambucano de Música e estavam colaborando com essa experimentação dessa nova música]. [...]. O baterista era professor de bateria do Conservatório, mas ele usou somente uma caixinha, para imitar o som da zabumba. ${ }^{16}$ Porque a gente convenceu a ele [pensamos que esse "ele" aqui é Ariano Suassuna] o seguinte: duas flautas e uma percussão já era um canal para representar a música da Zabumba ${ }^{17}$, ou do que eles chamam de quente ${ }^{18}$ de terno, terno de pifes, ou terno de pife.

Marília Santos: Um terno de pife são dois pífanos e uma zabumba, é isso?

Clóvis Pereira: É. E uma zabumba. Um bombo e uma caixa, e ninguém mais. Tem lugar aí $15 \quad$ Francisco Brennand (1927-2019) foi um artista plástico brasileiro que integrou o Movimento Armorial.

16 Aqui zabumba é o instrumento musical. Para não confundir o/a leitor/a, escreveremos com letra maiúscula $(Z)$ para a banda de pífanos e com letra minúscula $(\mathrm{z})$ para o instrumento musical. Atualmente os ternos de pífanos são chamados de bandas de pífanos e são formados basicamente por dois pífanos, o mais agudo e o mais grave, e por uma percussão formada pelos seguintes instrumentos: prato, caixa, contra surdo e zabumba. O terno de Mestre Ovídio, o qual Ariano Suassuna usava como uma das inspiraçóes para a música armorial, também tinha rabecas. A origem das bandas de pífanos também está relacionada com as chamadas bandas cabaçais. Nessas bandas era comum haver instrumentos de percussão feitos com cabaças. A cabaça é o fruto de uma planta. Quando está maduro, fica duro e serve para fazer várias coisas, inclusive instrumentos musicais.

17 Zabumba aqui é sinônimo de Banda de Pífanos.

18 Não temos certeza se ele disse a palavra "quente". O áudio ficou um pouco ruim nesse momento. 
que bota uma sanfona, porque não encontra o segundo do pífano. [...]. Eu, quando era menino em Caruaru, eu acho que foi a primeira coisa que eu escutei da rua, foi um terno de pífano passando na frente da nossa casa. Mas a gente em Caruaru não chamava nem terno, nem banda de pife, a gente chamava a Zabumba.

Marília Santos: Lá vem a Zabumba.

Clóvis Pereira: Lá vem a Zabumba.

Marília Santos: Eles passavam tocando no meio da rua?

Clóvis Pereira: Tocando no meio da rua. E às vezes tocavam na procissão, quando não tinha banda de música. Às vezes tocavam na feira.

Marília Santos: Isso era para quê? Para o povo dar dinheiro? Se quisesse...

Clóvis Pereira: É. Para dar um agradinho, uma moeda, uma coisa. Aí quando eu cheguei aqui, eu de tanto ouvir... Lá em Caruaru às vezes chamavam de matuá.

Marília Santos: Matuá é a mesma coisa?

Clóvis Pereira: É. A mesma coisa. E depois é que eu vim saber é que matuá, para o matuto, é, vamos dizer, uma porção de troços que você carrega [parte inaudível, mas parece que ele explica que carrega algo de um lugar para outro]. Aí eu disse aqui a Guerra-peixe: "Olhe, Guerra-Peixe, em Caruaru só se chamava matuá." E o dono da Zabumba tinha o apelido de Gato. G-A-T-O. Gato e sua matuá. "Lá vem Gato." "Lá vem a matuá de Gato." [...]. Porque minha mãe chamava matuá, meu pai chamava também. Ninguém chamava terno. Eu nunca vi ninguém chamar terno de pífano. E, talvez Zabumba, a gente também chamava Zabumba. Mas, quando eu era menor mesmo, eu nem sabia o que era Zabumba. Depois é que eu comecei a ouvir alguém chamar Zabumba e tal. Então a gente convenceu Ariano que botando as duas flautas, junto com a percussão, já era uma coisa representativa. Agora, Ariano só queria a rabeca. A rabeca e a viola [nesse caso é a viola de dez cordas].

Marília Santos: Ele queria a rabeca mesmo?

Clóvis Pereira: Não. Ele queria um violino... ele aceitava... que imitasse a rabeca, né? E... mesmo porque Cussy tinha recentemente, há uns cinco, seis anos atrás, tinha voltado da Suíça, diplomado como um violinista.

Marília Santos: Cinco, seis anos atrás referente aos anos setenta, né?

Clóvis Pereira: É. Aí Cussy não queria tocar numa rabeca, [...], que ele também não poderia dar um pouco de expressão, essa coisa.

Marília Santos: Que ele não poderia usar a técnica que aprendeu?

Clóvis Pereira: É. E a afinação também não seria muito característica. E no fim seria uma imitação, seria uma cópia menos original do que... uma cópia menos representativa do que o original. Então o pessoa ia dizer...

Marília Santos: A cópia menos representativa seria o quê? A utilização do violino?

ICTUS Music Journal vol. 15 n.2 
Clóvis Pereira: Sim. O violino imitando aquela maneira de tocar.

Marília Santos: Então, na sua concepção, isso é que teria que ser: a imitação daquela maneira [nesse caso, da rabeca]? Não a mesma música?

Clóvis Pereira: É... a mesma música... o crítico ia dizer: “ah, dá para fazer isso... traz o pessoal mesmo do interior."

Marília Santos: Que até toca melhor, né? O rabequeiro toca melhor [rabeca] do que o violinista [toca rabeca].

Clóvis Pereira: Claro. Mais espontâneo. E quando se toca o violino, a maneira, as arcadas que os rabequeiros usam, as escalas e o desenho da música... Agora, uma coisa que faz um rabequeiro, ou dois, oito violinos fazendo fica mais bonito, fica mais representativo daquela cultura. E botar mais duas violas [de arco] para fazer a harmonia e fazer o contracanto com os violoncelos. Essa era a forma que a gente queria dar artisticamente.

Marília Santos: Então a concepção de música armorial seria fazer uma cópia da música popular tradicional utilizando técnicas e instrumentos "clássicos"? É isso?

Clóvis Pereira: E usando o modo de tocar deles. E na música, a harmonia e a melodia, seguindo esses parâmetros.

Marília Santos: E esse modo, seria o quê?? A interpretação?

Clóvis Pereira: Seria a interpretação. O modo de tocar. A maneira de interpretar. E, da nossa parte, os compositores, que eram somente eu e Jarbas Maciel... E algumas vezes Cussy também, que compunha alguma coisa. Mas ele tinha muitos afazeres, se dedicava à direção do Conservatório [Pernambucano de Música], [...], e ele raramente tinha uma inspiração para fazer também uma coisa nordestina. Primeiro, porque ele não havia vivido essa coisa lá na cidade onde ele cresceu e se educou e começou a estudar música. Então, nós convencemos Ariano que não era o fato de colocar instrumentos europeus que a música que a gente fizesse, fosse fazer, iria lembrar a música europeia. $\mathrm{Ou}$, em outras palavras, para Ariano era descaracterizar o trabalho de pesquisa da orquestra nordestina. ${ }^{19}$ Ele achava que aquilo ali só apareceria se fosse usado a mesma roupa e o mesmo material que eles usavam.

Marília Santos: E vocês já pensavam diferente...

Clóvis Pereira: Já. A gente pensava em fazer uma música de concerto, que tivesse as características do Nordeste, que obedecesse as escalas, que ficaram lá como herança, longe do rádio e da televisão, né? Porque as cidades onde ficam o rádio e a televisão, a música dessas cidades vai ser, queira ou não queira, influenciada pelos compositores, pelas novas geraçóes, do que eles ouvem na rádio. E no interior, do Nordeste, não é? Eles são influenciados por aquilo que eles ouvem desde pequenos. [...]. Então o que levaram para o interior do estado, o interior do Brasil, isso ficou lá e reproduziu-se

19 Nesse momento o áudio tem uma certa falha, e por isso não temos $100 \%$ de certeza de que a palavra dita por Clóvis Pereira foi realmente "nordestina". 
lá. Modificou-se lá. Eu não discuto que não tenha sofrido modificações e influências passageiras. Mas muito longe do que o rádio na época divulgava. Eu alcancei uma época... Nos anos quarenta o que muitos divulgavam era música americana, nas rádios. Havia poucas gravadoras no Brasil. E quando gravavam um disco no Rio, vinha com influências pro $^{20}$ Rio de Janeiro. O samba, por exemplo, está completando agora cem anos. Mas antes do samba a gente não sabe, pelo menos eu não sei o que era a música carioca, porque eu nunca fiz um estudo sobre isso. Eu tô até para ler. Tem uma camarada aí que fez uns três ou quatro livros, pesquisou lá no Rio e tal. Ele disse que o samba já existia antes da primeira gravaçáo. É como o frevo. Essa história de o frevo nasceu em 1909, faz 100 anos, porque o jornal colocou o nome frevo, não sei o quê... Cem anos que publicou. Mas antes já tinha frevo. Porque ninguém vai fazer uma música: "Vou fazer um frevo." Não. Frevo antigamente, quando eu era menino em Caruaru, meu pai tocava na banda, e eu ia às vezes para os ensaios, quando eu tinha uns nove anos, oito anos, aí eu via: "Vamos tocar a marcha-frevo" Começou chamando marcha-frevo - de Levino Ferreira."

Marília Santos: Era o seu pai que era clarinetista ou era o senhor?

Clóvis Pereira: Era meu pai. Meu pai não queria que eu tocasse instrumento de sopro e nem queria que eu entrasse na banda. Mas eu era louco por música. De repente deu uma vontade. Quando eu cheguei aos doze, treze anos, já no ginásio, aí eu disse: "Pai, eu quero aprender música." Aí ele me trouxe um livro, me ensinou as primeiras liçôes. E eu fiquei cantando, solfejando, andava com o livro debaixo do braço. Ia para o ginásio... Estudei muito no ginásio. Fui um dos primeiros alunos, modéstia à parte. Mas quando chegou pelo terceiro ano ginasial, eu assisti um filme sobre a vida de Chopin e outro sobre a vida de George Gershwin... Meu pai trabalhava no cinema, passava os filmes, e eu ia para lá assistir junto com ele, ajudar ele a projetar os filmes. Aí eu disse: "Não! Agora eu vou estudar música de todo jeito." [...]. Eu tive sorte. Agradeço a Deus. Porque eu cheguei aqui [Recife] com dezessete anos. Estava no terceiro ano científico, já. Aí, - "O que é que você quer ser? Você quer ser médico?" - "Não. Não gosto. Não gosto de hospital." Aí, - "Dentista?", eu disse: "A mesma coisa." Aí disse: - "Você pode ser advogado." Entáo, eu ia para o cinema, e todo filme que aparecia o advogado, só aparecia um advogado [...] defendendo um criminoso, um bandido. [...]. Aí eu era assim meio trancado, aí eu dizia: - "Não tenho jeito para fazer discurso." Então também não quero advocacia. [...]. E dizia: "E engenharia?", e eu dizia: - "Olhe, eu sou péssimo em matemática." [...]. Eu tive a infelicidade de chegar no colégio e pegar um professor ruim, careta, mercenário, que ensinava pouco. Eu levava os livros para casa e náo sabia estudar sozinho para resolver aquelas fórmulas. Fazia errado. Quando eu levava para ele corrigir, ele soltava um piadazinha. Agora tirava dez em latim... [...]. Francês, eu era um dos melhores alunos. Inglês, que era o diretor do colégio que ensinava inglês. E ele deu uma bolsa para papai e mamãe, que a gente era de família pobre mesmo. Aí eu disse: - "Eu vou ser o melhor aluno da classe do diretor, para ele saber..." que tinha perguntado a minha mãe, eu me lembro, eu tinha onze anos, - "Ele é comportado?" - "É." Minha mãe disse: "É." - "Ele é estudioso?" - "É." Pronto. Então eu tinha que vender, eu tinha que mostrar isso, eu sentia no coraçáo.

20 Ficamos na dúvida se ele quis dizer "pro" ou "do". No áudio nos parece "pro".

ICTUS Music Journal vol. 15 n.2 
Marília Santos: Mostrar que valia a pena o que ele tinha feito, né?

Clóvis Pereira: Claro. Eu estava ali representando a palavra da minha mãe. Aí minha mãe dizia: "Meu filho, estude. Porque quem não estudar, não é nada na vida." Aí depois eu me entrosei com os alunos. Mas o cara de matemática me fez estudar um curso de um mês, na casa dele, pagando particular. Esse era um desonesto. E era um homem sem critério. Porque, como é que o sujeito ensina mal no colégio, e ensina bem em casa? Ele tinha uma garagem, com uma mesa enorme... Se chamava [preferimos não colocar o nome do sujeito]. Eu nem conhecia a família dele. Entáo tinha pelo menos vinte alunos. Tudo particular. E tudo ensinando bem. Ele sentava de mesa em mesa e explicava.

Marília Santos: E na escola ensinava mal?

Clóvis Pereira: Nada. E foi por isso que, quando eu vim de Caruaru, eu não entrei aqui no Ginásio Pernambucano, porque ele dizia: "Olhe, tem um professor de matemática que ensina mal. Ele na primeira semana mostra o livro e diz: 'O livro tem tudo. Leve para casa e estude.' Aí começava na outra semana: 'Fulano, pra lá, faça o problema número 1 aí e diga como está fazendo." Eu disse, "Eu vou estudar com um camarada desse... Oxe.” [...]. Mas a vida é assim, né? [risos].

Marília Santos: Me diga uma coisa: o senhor disse que hoje praticamente não existe música armorial. E música com influência armorial, o senhor consegue perceber?

Clóvis Pereira: Ah, eu consegui perceber que depois disso [acreditamos que ele está se referindo à estreia do Movimento Armorial], cantores como, eu conheci estreante ainda aqui na televisão nos anos sessenta, esse que hoje é famoso, que é lá do interior, é... ele aparece muito no São João com Elba Ramalho.

Marília Santos: Alceu Valença?

Clóvis Pereira: É. Alceu Valença. Alceu Valença, a primeira vez que foi pro Rio cantar num festival, eu fui com a orquestra ${ }^{21}$, que a televisão me mandou, porque era a orquestra do festival. Como ele era um cantor... náo era conhecido como cantor, e sim, ele venceu um concurso. Não é verdade? Através de uma gravação. Cantou lá [inaudível] no rádio, com a orquestra da gente. E tinha umas meninas de Garanhuns, que a gente chamava: as irmãs Alciomay ${ }^{22},[\ldots .$.$] . E eu fui para reger a orquestra para essa dupla$ feminina. Depois que a música armorial, quatro ou cinco anos depois, começou a aparecer, ele [Alceu Valença] começou a se ligar mais nas músicas da terra dele, do interior, começou a fazer a música com sotaque armorial, que a gente chama. Com a melodia com a quarta aumentada e a sétima abaixada. E até inventar músicas, de fato, eu acho que ele sabia, porque ele foi criado no interior, e desenvolveu aquilo e começou a fazer sucesso. As rádios começaram a tocar. Tinha uma rádio que tocava com um prefixo "Mouráo". Tinha um conjunto aqui com aquele menino que toca rabeca, que é... [...].

21 Não fica claro se é a armorial ou outra orquestra. Inclusive, numa fala anterior ele fala anos sessenta e não setenta.

22 Não temos certeza se foi realmente essa palavra que ele disse. Mas, pela pronúncia, se não for isso, é algo muito parecido. 
Marília Santos: Antonio Nóbrega?

Clóvis Pereira: Antonio Nóbrega. Antônio Nóbrega que fez um conjunto ${ }^{23}$ com...

Marília Santos: O Quinteto Armorial? É isso que o senhor está querendo falar?

Clóvis Pereira: É. O Quinteto Armorial. Que tinha um rapaz também que trabalhava para Ariano, na música armorial.

Marília Santos: Antônio Madureira?

Clóvis Pereira: Antônio Madureira. Que eu achava bom você fazer uma entrevista com ele.

Marília Santos: Amanhã.

Clóvis Pereira: Opa! Então você está no caminho certo. Porque Madureira ficou cuidando mais dessa parte, que tinha a rabeca, do menino, Antonio Nóbrega, e ele [Antônio Madureira] tocava violáo... e tinha um irmáo dele, que depois fez um balé. ${ }^{24}$

Marília Santos: Antúlio, né? Antúlio Madureira. Só que não era do Quinteto, não.

Clóvis Pereira: [...]. Então o Antônio Madureira depois ficou com um conjunto trabalhando com Ariano nas aulas-espetáculo. [...]. O movimento, depois, Ariano parou com o pessoal do Conservatório. Ele se desentendeu com Cussy. Entáo ele deixou de me procurar e deixou de procurar Jarbas.

Marília Santos: E vocês não tinham nada a ver com o desentendimento deles, né?

Clóvis Pereira: Não tinha nada a ver. É.

Marília Santos: Mas vocês [Clóvis Pereira e Jarbas Maciel] estavam [frequentavam e/ou trabalhavam] no Conservatório nessa época? Acho que ele [Ariano Suassuna] ficou meio receoso... [Cussy de Almeida trabalhava no Conservatório Pernambucano de Música quando isso aconteceu].

Clóvis Pereira: É. Ele [Ariano Suassuna] teria que nos encontrar no Conservatório... [...]. Quem sabe se ele não pensou que nós estivéssemos também ao lado de Cussy. Com o que Cussy aprontou que ele não gostou.

Marília Santos: Ah, Cussy aprontou?

Clóvis Pereira: Aprontou um negócio que ele [Ariano Suassuna] não gostou. [...]. Porque ele também gostava de música "bonita" [Esse bonita, pela conversa, seriam as músicas midiáticas, que tocavam na rádio. Porém, devemos mencionar que a música da Orquestra Armorial de Câmara de Pernambuco também se destacou por conta da rádio].

Marília Santos: Ele quem? Cussy?

23 Esse conjunto é o Quinteto Armorial, que nasceu do encontro de Ariano Suassuna com Antônio Madureira, um dos integrantes do grupo. Antônio Nóbrega, assim como os demais integrantes, foi convidado para performatizar esse trabalho.

24 Essas informaçóes de Clóvis Pereira são sobre o Quinteto Armorial. Antúlio Madureira, irmão de Antônio Madureira, se envolveu com os trabalhos de Ariano Suassuna, mas náo com o Quinteto Armorial. 
Clóvis Pereira: Cussy. Eu digo bonita entre aspas, que para agradar ao povo, ele, no fim do programa, botava músicas populares [mais uma vez entendemos que Clóvis Pereira está se referindo às músicas que tocavam na rádio]. Música de Caetano Veloso... Ele pedia para eu fazer arranjo de música americana, pedia para eu fazer arranjo de... [...].

Marília Santos: Isso era com a Orquestra Armorial?

Clóvis Pereira: Era a mesma. Ia fazer um concerto armorial, anunciava. Aí quando Ariano estava, ele [Cussy de Almeida] também só tocava armorial. E às vezes, ele não queria reger, por uma razão ou outra, aí eu tomava a regência. E uma vez ele [Cussy de Almeida] fez um concerto no Jornal do Comércio, no dia do jornalista. [...]. E o concerto foi um sucesso. Mas os rapazes estavam ali [no prédio do Jornal do Comércio] trabalhando - pela primeira vez eu vi como era uma redação dum jornal, né? Uns vinte. Cada um com uma máquina datilográfica, escrevendo. Notícia, né? Um falava com o outro [...]. Aí eles pararam para ver o concerto. Tocamos cinco, seis músicas. Aí quando eles sentaram para trabalhar, aí tocou ainda uma música armorial. Mas eles ainda aplaudiram. Menos. Menos, né? [...]. Porque eles tinham que entregar o trabalho para o jornal... [...]. Aí ele [Cussy de Almeida] tocou... ${ }^{25}$ mas eu não lembro mais das músicas. Três ou quatro músicas.

Marília Santos: Essa músicas midiáticas, que passam na rádio, né?

Clóvis Pereira: Mi-di-á-ti-ca. Música cantada pela irmã de Caetano Veloso, música... eu não lembro mais.

Marília Santos: Coisa que Ariano já era contra, né?

Clóvis Pereira: É. Coisa que Ariano eu acho que nem ouvia. Se ouvisse desligava o rádio. Aí, como era música de sucesso, aí o pessoal bateu palmas [Clóvis fez o gesto das palmas de maneira vibrante]. O pessoal se levantou, aí ele [Cussy de Almeida] outra música de sucesso [A expressáo é para dizer que cada vez que as pessoas se animavam com as músicas, Cussy de Almeida colocava mais outra música desse tipo para ser tocada pela orquestra]. Ariano não estava presente. Mas Ariano já havia pedido a ele: "Cussy, não misture, porque a gente quer mostrar uma cultura. Eu não quero mostrar outra cultura que o rádio já mostra." [...]. Mas, o diabo é que o jornal, no dia seguinte, deu a notícia assim: "a Orquestra Armorial de Câmara compareceu..." náo sei se essas eram as palavras, fez uma apresentação do trabalho armorial, tal, tal, tal, aí o jornalista disse [a partir daqui Clóvis Pereira narra a história rindo]: mas o sucesso mesmo aconteceu quando a orquestra apresentou as músicas tais e tais...

Marília Santos: Que eram a populares? Da mídia?

Clóvis Pereira: Eram as populares. Era.

Marília Santos: Ariano deve ter ficado...

Clóvis Pereira: Ô! Ariano fez uma carta pra ele. Ariano nunca mais nem o procurou para tomar satisfação.

25 Na verdade foi a Orquestra Armorial de Câmara de Pernambuco que tocou. Cussy de Almeida regeu. É uma maneira de falar, dizer que o regente tocou. 
Marília Santos: Isso era mais ou menos que ano?

Clóvis Pereira: Ah, isso foi... Deixa eu ver agora. 1970 estreou. Em 71 nós viajamos para o Rio, para [inaudível], para Brasília. Aí depois dessa viagem do Rio eu me afastei. E ele ficou usando o repertório, que já era grande, já tinha dois ou três discos gravados. Aí eu assumi, de fato, o compromisso com a Universidade do Rio Grande do Norte. Comecei a viajar mais vezes. E, eu não sei precisar a data.

Marília Santos: Mas foi antes de 75 ?

Clóvis Pereira: Foi. [...]. Depois eu soube que ele viajou várias vezes para Brasília. Eu me lembro que ainda teve um concerto aqui para o presidente, da revolução deles, Costa e Silva, parece, no Grande Hotel. Depois fizemos em Brasília também, Porto Alegre, Sáo Paulo e Rio. E depois diminuiu, e ele ficou fazendo. Até que eu nem me lembro como é que acabou.

Marília Santos: Eu conversei com um jovem. Ele não me deu muitos detalhes, mas ele disse que ele faz parte de um grupo de compositores que está levantando materiais para compor música armorial. O que o senhor acha disso?

Clóvis Pereira: Eu acho bom. Eu acho válido.

Marília Santos: Então o senhor acha que a pessoa que diz [hoje] que está compondo música armorial, ela está mesmo compondo música armorial?

Clóvis Pereira: Está. Se ela seguir as escalas, as formas rítmicas, a harmonização, os acordes.

Marília Santos: Ah. Então tem que está dentro [de acordo com] disso?

Clóvis Pereira: É. Eu escrevi para meu filho um concerto para violino. Eu não botei o nome de concerto armorial. Mas ele tem muitas características armoriais. E meu filho tocou esse concerto já em São Paulo... na Paraíba... e tem tocado por aí, no Rio de Janeiro... E depois, um grande cellista brasileiro, você deve conhecer, chamado Antônio Meneses, que é daqui de Pernambuco, [...]. O pai dele tocava na Orquestra Sinfônica, com a gente, tocava comigo também, na rádio. Então o pai dele mudouse para o Rio. E como os filhos tinham muito talento [Clóvis Pereira fala no plural mesmo], ele colocou o filho para estudar violoncelo, porque ele achava muito bonito. O pai era trompista.

Marília Santos: No caso, o filho era Antônio Meneses?

Clóvis Pereira: O filho era Antônio Meneses. O pai dele se chamava João Meneses. João Gerônimo Meneses.

Marília Santos: Que era trompista?

Clóvis Pereira: Que era trompista aqui da sinfônica. Foi trompista da rádio, do Teatro Municipal, onde se aposentou, da Sinfônica Brasileira, e era amigo da gente, muito conhecido. Quando eu cheguei aqui, e estava começando na rádio, ele já era [inaudível]. E, como eu estava dizendo, [...], [Esse trecho ficou com muitas partes cortadas. 
Clóvis Pereira explica que foi à casa de alguém, no Rio de Janeiro. Mas depois fala em São Paulo]. Eu fui em São Paulo [Talvez ele tenha se confundido com a cidade ou entáo foi um encontro onde ele e o Antônio Meneses estavam em Sáo Paulo] e conheci Antônio Meneses. Eu o conheci menino. Tocou para mim com dez anos. Já era, tocando concerto, já era uma coisa louca. A professora saia de casa para dar aula a ele em casa, se ele não chegasse na hora. Ela dizia: "Ah, pode ser que não tenha tido o dinheiro da passagem para ir para a aula. Pode ser que ele esteja adoentado." A professora [inaudível]. Dava aula de graça. Até que esse menino com quatorze, quinze anos, foi ouvido por um grande cellista brasileiro e "Vamos para a Europa comigo? Você vai morar comigo lá em casa, comigo. Eu vou lhe ensinar." E ele [Antônio Meneses] chegou a vencer o maior concurso do mundo, que é o Concurso de Moscou ${ }^{26}[\ldots]$. E vai gente de todo o mundo. Entáo esse menino, Meneses, que me conhecia de vista, porque depois ele cresceu, e eu não fui mais no Rio, e o pai dele faleceu também, aí ele disse: "Ah, eu vi um negócio meu armorial." [Nesse trecho Clóvis Pereira faz uso do discurso indireto livre. Ele começa narrando como se fosse reproduzir a fala do Antônio Meneses, e termina falando ele mesmo. O que aconteceu é que Antônio Meneses viu/ouviu algo armorial do Clóvis Pereira]. Aí, Oxe! Ele ligou para mim. Aí o telefone: "Com quem eu falo?" "É fulano, filho de fulano, seu amigo e tal. Vou tocar no Recife, em dezembro, e quero que você escreva uma coisa para eu tocar."

Marília Santos: Isso foi mais ou menos quando?

Clóvis Pereira: Isso foi em 2002, 2004, por aí. Aí eu disse: "Vou pensar." Mas fiquei assim, sabe? Acanhado. Porque esse menino já tocou na Rússia, em Berlim, em Nova Yorque, em todo lugar, as peças mais bonitas de violoncelo, as peças mais complicadas tecnicamente, virtuosísticas, né? Eu disse comigo: “O que eu vou fazer?” E ele tinha dito, para não me desanimar, eu disse: "Eu não sei se dá tempo." ele disse: "Escreva uma página. Nem que seja uma página, para violoncelo solo." Aí eu fiquei pensando, fiquei pensando... eu digo: "Num vou escrever nenhuma página. Depois eu dou uma desculpa." Mas aí eu pensei depois, no outro dia: "Isso é uma oportunidade, de eu ser executado, uma música minha, por um solista mundial.

Marília Santos: Que lhe pediu.

Clóvis Pereira: Que me pediu. É isso, né? Dizer que queria para apresentar no Recife. Aí, eu tava na cama, aí eu olhei assim pra cima, aí vi, vi como se estivesse no papel, um compasso [ele canta uma melodia curta], três compassos, quatro. Levantei da cama, cheguei aqui no computador, e julguei escrever essa ideia. E pensei que voltava para dormir. Eu digo: "Não. Agora essa ideia eu vou transportar. Aqui, a resposta é uma quarta acima e tal. E fui fazendo e tal e tal. Fui dormir cinco horas da manhã.

Marília Santos: Mas fez todinha?

Clóvis Pereira: Não fiz todinha, não.

Marília Santos: Mas fez muita coisa?

26 É o Concurso Tchaikovsky, em Moscou, na Rússia. Ele venceu em 1982. 
Clóvis Pereira: Aí foi crescendo. Aí eu disse: "Eu vou fazer a primeira página, eu vou fazer como se fosse a primeira parte de um concerto." Disse. Depois se tornaria concerto. Aí tinha uns quarenta dias que eu fazia isso. Eu trabalhava todo dia nisso. E te juro que não consultei o piano uma vez.

Marília Santos: Só escrevendo?

Clóvis Pereira: Só escrevendo. As ideias vinham na cabeça. Uma ideia mostrava outra.

Marília Santos: Como se chama essa peça?

Clóvis Pereira: Concertino, olha a modéstia, Concertino para Violoncelo e Orquestra de Cordas.

Marília Santos: Ah, o senhor fez para orquestra também. Não foi para violoncelo solo, não.

Clóvis Pereira: Foi. Foi. Eu fui vendo que dava para fazer a orquestra.

Marília Santos: Então deve ter na internet, né?

Clóvis Pereira: Não sei se tem, não. Mas tem a gravação. No comércio, saiu. Eu cheguei a distribuir mais de cinquenta discos aqui. Eu não posso lhe dar um porque não tenho mais. Os últimos que tinha, eu peguei essa semana para João Pessoa, para dar uma para o maestro da orquestra, um rapaz que foi professor do meu filho. O rapaz foi professor de violino do meu filho quando ele era pequeno. Ele ficou maravilhado com o concerto. ${ }^{27}$ Disse: "Por que não faz um todo ano? Ou um a cada seis meses?"

Marília Santos: É. Concordo.

Clóvis Pereira: Eu digo, sabe o que é que falta? Falta o ambiente.

Marília Santos: E é?

Clóvis Pereira: Eu só trabalho assim, motivado pelo ambiente.

Marília Santos: E é?

Clóvis Pereira: É. Eu sou assim. Eu preciso de motivação. Preciso estar junto de uma orquestra, vendo a orquestra tocar. Ter contato com os músicos. Tendo contato com música.

Marília Santos: Ah, o ambiente musical, né?

Clóvis Pereira: Mas eu abusei ${ }^{28}$ até da sinfônica. Toquei quarenta anos na sinfônica. No contrabaixo. Regi a sinfônica várias vezes. Compus pra sinfônica, umas duas ou três peças, e compus concertos, esses dois concertos. [...]. Eu fiz uma música em 67, 68, antes até do armorial, eu fiz uma música sinfônica. Foi a primeira música que eu pedi ao maestro para escrever, quando eu entrei na sinfônica, para poder ouvir muito a

27 Aqui náo sabemos se ele ainda está falando sobre o concerto para violoncelo ou sobre o concerto para violino, que ele escreveu para o seu filho violinista, Clóvis Pereira Filho. No final de semana anterior a esta entrevista, Clóvis Pereira Filho havia tocado esse concerto em João Pessoa, na Paraíba, e Clóvis Pereira havia ido assistir.

28 Náo temos certeza se foi mesmo essa palavra que ele disse. Mas parece isso. 
sinfônica e ter dentro do [inaudível] da sinfônica, como era o naipe de cordas, como era o naipe de madeiras, o naipe de metais. E compus uma música assim, imaginando a orquestra. Fui fazendo. [A partir daqui Clóvis Pereira começa a falar de um fato mais atual]. Aí um regente da Paraíba, chamado Arlindo Teixeira, que é um jovem, um bom regente, foi convidado para reger num dia, e ele queria encerrar o concerto com minha música. E tinha uma música de Villa-Lobos. Aí Marlos Nobre ${ }^{29},[\ldots]$, disse: "Você encerra com Villa-Lobos. Agora você bota Clóvis Pereira na primeira parte." Aí Arlindo disse: "Não. Eu boto começando a segunda parte. Não. Na primeira parte eu não boto." Aí ele concordou. Mas enquanto Arlindo [ensaiava a orquestra], ele [Marlos Nobre] só chegava no concerto, no final do concerto, do ensaio.

Marília Santos: Quando tinha Villa-Lobos?

Clóvis Pereira: É. Aí ele só via o Villa-Lobos. Mas quando ele foi para o teatro, ele conheceu a primeira peça, conheceu a segunda. Quando começou [a segunda parte do concerto], ele começou a ver a minha peça. Ele ficou impressionadíssimo. [...]. E depois, na hora dos cumprimentos, ele foi falar com Arlindo, e disse: "Ô Arlindo, cadê a partitura da música de Clóvis? Ah, vá buscar. Manda buscar." Aí ele pediu licença e foi olhar a partitura, porque ele ouviu um som que agradava ele, é óbvio. Não é verdade? [...]. Aí, a primeira vez que me viu no Rio, eu fui chegando no Teatro Municipal, ele: "Apareça lá no Instituto. Eu tô com a gravação da sua música separada, e tal, para lhe dar." Chegou em Brasília, um ano ou dois depois, num encontro de compositores, e ele estava lá: "Rapaz, você não foi buscar a sua música." [...].

Depois Clóvis Pereira conta mais algumas histórias.

Marília Santos: Então é isso, né?

Clóvis Pereira: É isso.

Marília Santos: Muito obrigada.

Depois disso eu parei de gravar. Mas o Clóvis Pereira além de agradecer, de conversar sobre várias outras coisas, disse que quando eu o liguei, pedindo para entrevistá-lo, porque estava fazendo uma pesquisa sobre a música armorial, pensou: "Eu não posso deixar de atender essa menina, que vem lá de Caruaru - na verdade é de São Caitano - para saber sobre a música armorial, para aprender sobre música armorial.” A seguir temos um registro desse dia, logo após a entrevista ser finalizada (Fig. 1). 
Figura 1. Clóvis Pereira e Marília Santos, após a entrevista, na casa de Clóvis Pereira

Fonte: Acervo pessoal.

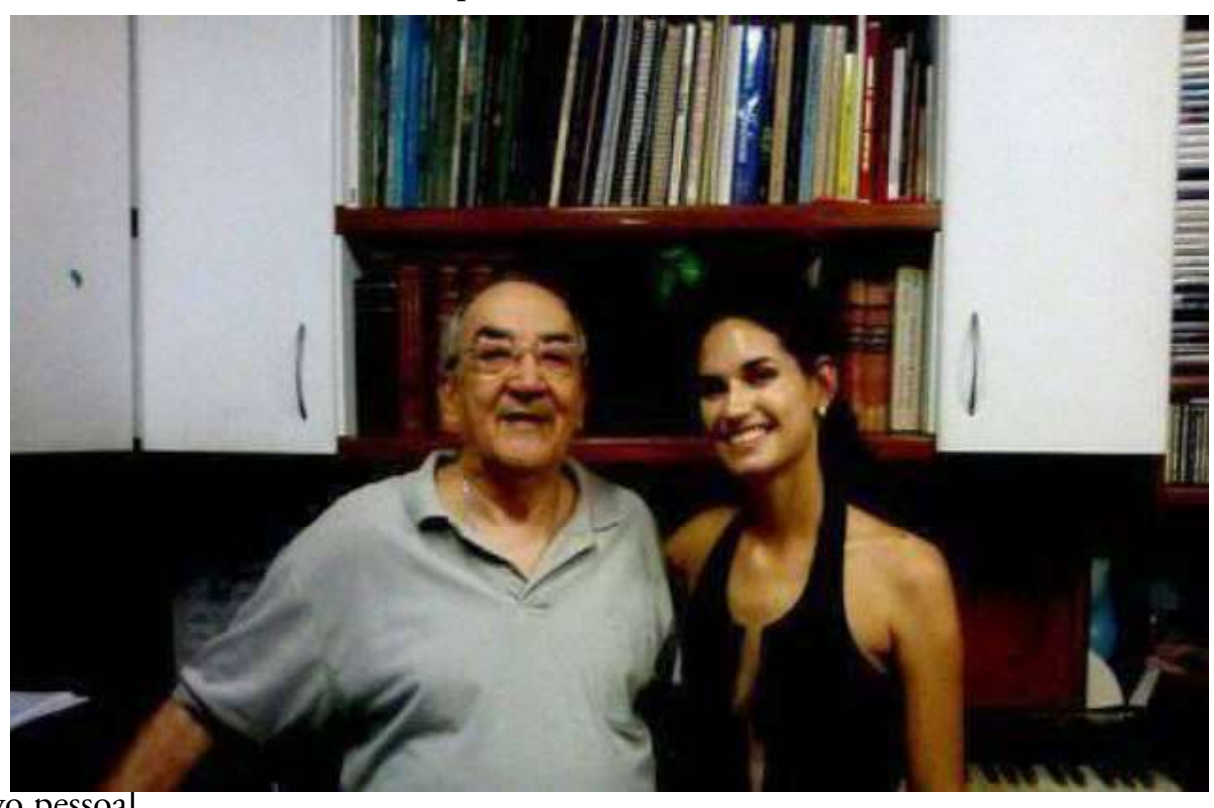

\section{Referências}

MORAES, Maria Thereza Didier. Emblemas da Sagração Armorial: Ariano Suassuna e o Movimento Armorial 1970/76. Recife: Editora Universitária da UFPE, 2000.

NÓBREGA, Ariana Perazzo da. A música no Movimento Armorial. Dissertação (Mestrado em Música). Universidade Federal do Rio de Janeiro, Rio de Janeiro, 2000.

NÓBREGA, Ariana Perazzo da. A música no Movimento Armorial. In Anais da Anppom. 2007, p. 1-13. Disponível em <https://hugoribeiro.com.br/biblioteca-digital/Nobrega-musica movimento armorial.pdf.>. Acesso em 01 ago. 2020.

PEREIRA, Clóvis. Entrevista de Marília Santos. Áudio. Recife. Em 13 mar. 2017.

SANTOS, Marília P. Ecos Armoriais: influências e repercussão da Música Armorial em Pernambuco. Dissertação (Mestrado em Música). Universidade Federal da Paraíba, João Pessoa, 2017.

SANTOS, Marília P. Ecos Armoriais: influência e repercussão da Música Armorial em Pernambuco. Música Popular em Revista, v. 2, ano 6, jul.-dez. 2019, p. 29-54.

SANTOS, Marília P. Música armorial: revisão bibliográfica. Revista Música, v. 20, n. 2, dez. 2020, p. 63-98.

SUASSUNA, Ariano. O Movimento Armorial. Recife: Editora Universitária da UFPE, 1974. 